\title{
Zimbabwe: \\ A Quest for a Nominal Anchor
}

Arto Kovanen 


\title{
IMF Working Paper
}

\author{
African Department \\ Zimbabwe: A Quest for a Nominal Anchor \\ Prepared by Arto Kovanen ${ }^{1}$ \\ Authorized for distribution by Hugh Bredenkamp
}

July 2004

\begin{abstract}
This Working Paper should not be reported as representing the views of the IMF. The views expressed in this Working Paper are those of the author(s) and do not necessarily represent those of the IMF or IMF policy. Working Papers describe research in progress by the author(s) and are published to elicit comments and to further debate.

This study examines the appropriateness of alternative intermediate monetary policy targets for Zimbabwe in light of the stability of the demand for money and the information content of financial variables for predicting price level movements. Results of the study indicate that a well-defined long-run demand relation exists for currency in circulation, but not for other monetary aggregates. Currency in circulation has strong information content for predicting future price level movements. The information content of other financial variables, such as the exchange rate and interest rates, is weaker. Statistical relationships break down of the outset of high inflation.
\end{abstract}

JEL Classification Numbers: E31, E41, E61

Keywords: Monetary policy, demand for money, nominal anchors, and inflation Author’s E-Mail Address: Akovanen@imf.org

\footnotetext{
${ }^{1}$ The author thanks Vivek Arora, Ashok Bhundia, Rodolphe Blavy, Hugh Bredenkamp, Paul Cashin, David T. Coe, Louis Erasmus, G. G. Johnson, Jean-Claude Nachega, Obert Nyawata, Luca Ricci, Doris Ross, Ratna Sahay, and Matthias Vocke for their comments. $\mathrm{He}$ is also grateful to Thomas Walter for editorial assistance. The usual disclaimer applies.
} 


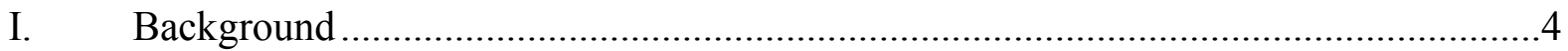

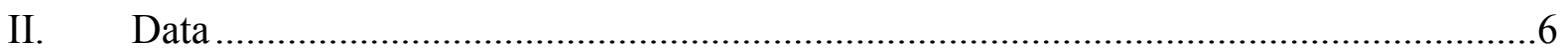

III. Information Content of Financial Variables .......................................................

IV. A Quest for a Nominal Anchor .......................................................................

A. Full-Sample Estimates ............................................................................. 11

B. Estimates for the Subperiod 1980: 1-1995: 12 ............................................13

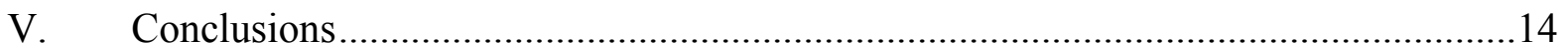

Appendix

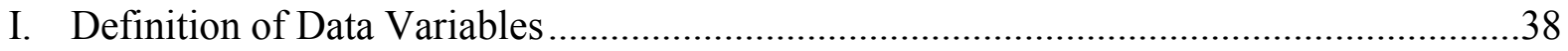

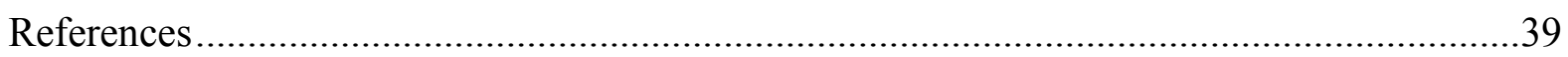

Box

1. Summary of Results for Selected Studies of Long Run

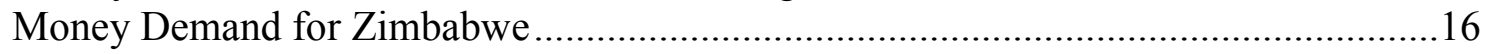

Tables

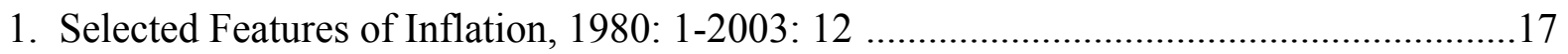

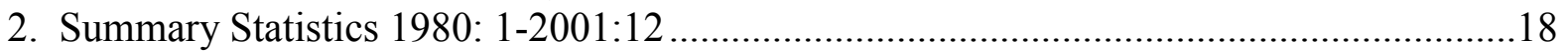

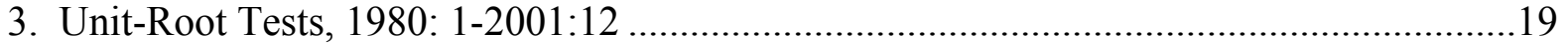

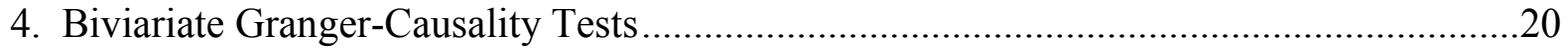

5a. Multivariate Granger-Causality Tests, 1980: 1-2001:12 .........................................21

5b. Multivariate Granger-Causality Tests, 1980: 1-1995:12 …....................................21

5c. Multivariate Granger-Causality Tests, 1996: 1-2001:12 ….....................................21

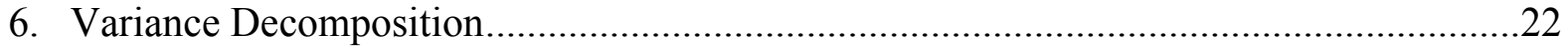

7. Unrestricted Cointegration Estimates for Currency in Circulation 1980:1-2001:12 .......23

8a. Currency in Circulation: Test for Normality of the Residuals, 1980:1-2001:12 _...........24

8b. Residual Correlation Matrix, 1980:1-2001:12 _.......................................................25

9. Pairwise Granger Causality/Block Exongeneity Wald Tests, 1980:1-2001:12 _............26

10. Unrestricted Cointegration Estimates for Currency in Circulation, 1980:1-1995:12 _.....27

11a. Currency in Circulation: Test for Normality of the Residuals, 1980:1-1995:12 ...........28

11b. Residual Correlation Matrix, 1980:1-1995:12 .....................................................29

12. Pairwise Granger Causality/Block Exogeniety Wald Tests, 1980: 1-1995:12 ..............30 
Figures

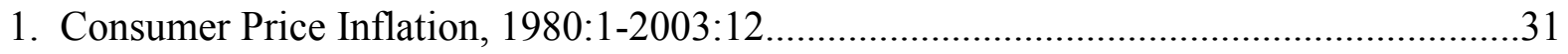

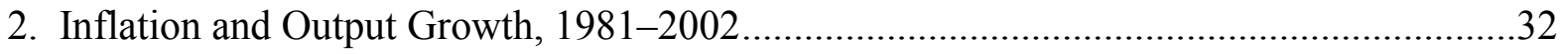

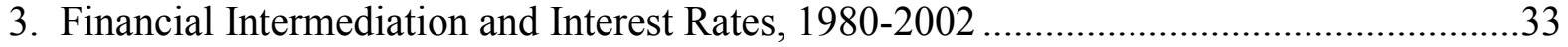

4. Treasury Bill and Three-Month Bank Deposit Interest Rates, 1980:1-2003:10 ..............34

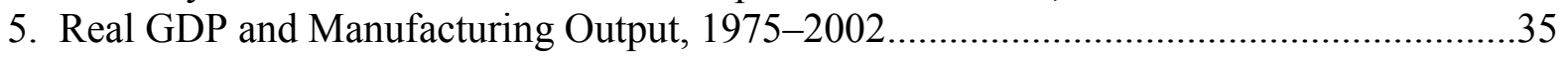

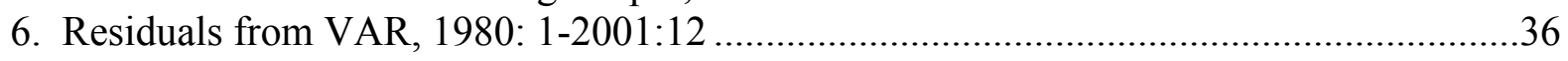

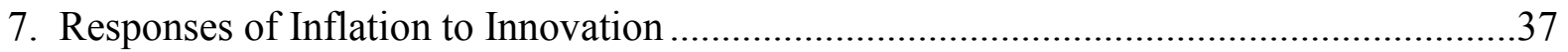




\section{BACKGROUND}

Zimbabwe is in the midst of its worst economic downturn since it achieved independence in 1980. Real output has fallen by one-third since 1999. Unemployment has risen sharply and has become pervasive and widespread. Social conditions are eroding rapidly, owing to weak economic policies and mismanagement. ${ }^{2}$ Public services are stretched to their limits, in part reflecting the high incidence of HIV/AIDS, resource constraints, and emigration. Economic hardships have taken a huge toll on the population, with the poor suffering the most.

Consumer price inflation in Zimbabwe has risen steadily during the past two decades (Table 1 and Figure 1). The volatility of inflation, measured by the standard deviation of annual inflation, has risen considerably, in particular during 2000-2003 when inflation accelerated. Movements in the exchange rate have coincided with changes in the price level, suggesting that the exchange rate adjusted for inflation may have been broadly appropriate in the past, except for the period 1999 when movements in the official exchange rate have not kept pace with the rise in inflation. ${ }^{3}$ Inflation has moved inversely to output growth (Figure 2).

High inflation distorts resource allocation and complicates economic management. Further, it undermines incentives for productive investment and reduces productivity growth. Research points out that high inflation exerts a disproportionate effect on the welfare of the poor (see, for example, Easterly and Fischer, 2001). Large fiscal deficits and foreign exchange market distortions, which are often causes of inflation, adversely impact real growth (Fischer, 1993). Because of these adverse effects of high inflation on economic development, macroeconomic policies are best geared toward maintaining low inflation. Across the world, as a result of policies aimed at lowering inflation, inflation has displayed a declining trend since the mid1990s, for both developing and industrial countries. Among African countries, annual average inflation has fallen to about 10 percent in $2003 .^{4}$

The authorities in Zimbabwe have experimented with several monetary policy frameworks to contain inflation, including exchange rate and monetary-based anchors, but these attempts did not achieve credibility owing to fiscal dominance. For example, the government granted

\footnotetext{
${ }^{2}$ Zimbabwe experienced severe droughts in 2001-2003, which added to the economic problems and required large-scale food imports by the government and donors to supplement the local crops.

${ }^{3}$ However, the instantaneous correlation between the official exchange rate and prices is rather low, about 33 percent in the full sample. Furthermore, comovements in the exchange rate and the price level should not be interpreted as suggesting causality between these variables

${ }^{4}$ Table 8, IMF World Economic Outlook, September 2003.
} 
large pension increases for war veterans in 1997 that were unbudgeted, thereby contributing an important way to the exchange crisis that followed. In 1999, the authorities fixed the official exchange rate. Because official reserves were low and the exchange rate policy was not supported by other macroeconomic policies, particularly fiscal policy, it failed to provide a credible nominal anchor for the economy. As a result, the real exchange rate appreciated rapidly and a significant parallel exchange market emerged. Foreign exchange shortages in the official market forced the authorities to devalue the official exchange rate in August 2001 , with an announced policy of adjusting the exchange rate in line with actual inflation. However, after a few months, the authorities abandoned the crawling-peg exchange rate regime and kept the exchange rate unchanged until February 2003, when the exchange rate was devalued for most external transactions. In the meantime, the parallel market exchange rate depreciated rapidly.

Financial markets in Zimbabwe have undergone significant changes during the past two decades, particularly following the financial liberalization of the early 1990s, which increased financial intermediation, as evidenced by the rise in the ratio of bank deposits to currency (Figure 3). An important factor behind financial deepening was the liberalization of bank interest rates in the early 1990s, which increased the attractiveness of interest-bearing deposits by providing positive real return. ${ }^{5}$ However, the failure to contain fiscal deficits after that led to an explosion of fiscal financing needs in the late 1990s, which were met, to a large extent, from domestic sources. This crowded out private sector credit and resulted in high real interest rates, while investors shifted away from bank deposits-to-treasury bills as the spread between deposit rates and treasury bill yields widened (Figure 4). In response to high nominal and real treasury bill rates, the government restructured its domestic public debt in January 2001, which led to a collapse of interest rates. Real interest rates became highly negative and demand for currency and foreign exchange increased, which contributed to inflation. In these circumstances, monetary policy became powerless to offset increases in inflation pressures, and the Reserve Bank of Zimbabwe had no policy autonomy in setting interest rates. ${ }^{6}$

Research on inflation and its determinants in Zimbabwe has been limited. Odedokun (1997), using pooled annual data for 32 sub-Saharan African countries, including Zimbabwe, finds that currency depreciation in the official and parallel markets, monetary growth, and foreign inflation have had significant impacts on domestic inflation. Jenkins (1999) and Nyawata (2001) examine the demand for money in Zimbabwe using quarterly data and establish longrun relations between money and the price level for currency, bank deposits, and narrow and

\footnotetext{
${ }^{5}$ The number of financial institutions also grew as indigenous players entered the financial market.

${ }^{6}$ See the discussion about the relationship between fiscal deficits and inflation in International Monetary Fund, World Economic Outlook, May 2002.
} 
broad moneys (see Box 1). ${ }^{7}$ The existence of this type of relationship is essential for a successful money-based stabilization.

This study builds on the earlier research. It examines the dynamics of inflation in Zimbabwe and its determinants, as well as its implications for the conduct of monetary policy. The study uses a broad set of econometric techniques to analyze the monetary transmission process in Zimbabwe. Monthly data spanning 22 years is utilized. The paper is structured as follows. Section II discusses data issues. Section III analyzes the causal relationship between the price level and financial market variables using bi- and multivariate Granger-causality tests. (Variables are explained in the appendix.) In this section, a vector-autoregressive (VAR) model is estimated that will explain to what extent fluctuations in the price level can be explained by its own variance and to what extent they are caused by the variance of other variables. Section IV moves the discussion to the long-run relationship between the price level and financial variables. In order to consider the anchor role of financial variables, one needs to establish whether there is a well-identified relationship between the variables included in the analysis. The presence of cointegration between the price and financial variables would suggest that a monetary variable is "anchoring" price expectations. This study estimates long-run money-demand relations for currency in circulation and reserve, narrow, and broad money aggregates. Section V concludes and discusses the implications of the results for monetary policy implementation in Zimbabwe.

\section{DATA}

The empirical analysis is based on monthly data for the period 1980:1-2001:12, including the early years of the most recent economic downturn. In view of the data limitations regarding, in particular, real GDP, which is available annually, monthly GDP data has been generated by utilizing the seasonal pattern of the monthly manufacturing data. Although manufacturing output only represents about 20-25 percent of total output in Zimbabwe, it correlates highly with real GDP at the annual level and therefore appears appropriate (Figure 5). ${ }^{8}$ We use four different definitions of money: currency in circulation, reserve, narrow, and broad money aggregates, and two interest rates (3-month treasury bill rate and 3-month time deposit interest rate). The latter performs better in econometric tests but the two move closely (see Figure 4).

${ }^{7}$ Jenkins (1999) offers a well-written and detailed analysis of the financial developments in Zimbabwe from 1976 until 1996 and discusses the use of various variables in estimating the money demand function for Zimbabwe.

${ }^{8}$ The correlation between the annual growth rates of manufacturing and real GDP is 0.77 . In addition, manufacturing production is to a large extent dependent on agricultural production, a key economic sector in Zimbabwe, as about two-thirds of manufacturing uses agricultural products as inputs. Jenkins (1999) uses agricultural output as a proxy for quarterly real GPD while Nyawata (2001) uses manufacturing output. 
The period-average official exchange rate against the U.S. dollar is used as a proxy for the expected returns on foreign currency, in the absence of a continuous time series for the parallel market rate. This variable was also adopted by Jenkins (1999), who notes that "illegal transactions in the foreign currency markets by wealthier Zimbabweans have tended to occur at the official exchange rate through the current account rather than at the parallel market rate (see page 406 of Jenkins, 1999)." All time series have been seasonally adjusted except interest and exchange rates, which do not exhibit seasonal patterns. Summary statistics are provided in Table $2 .{ }^{9}$

\section{INFORMATION CONTENT OF FINANCIAL VARIABLES}

We begin by examining the significance of each financial variable for determining the price level using bi- and multivariate Granger causality tests. The approach adopted here follows Bernanke and Blinder (1990). The marginal significance levels of bivariate causality tests for the full sample and for two subsamples are reported in Table 4. The results suggest that currency in circulation is a significant predictor of the price level whereas other financial variables are generally not. Real GDP Granger-causes changes in the price level in the full sample, pointing to the importance of possible supply-side explanations for price level movements. During the period 1996:1-2001:12, the causality of output reverses itself, suggesting that high inflation has adversely affected output growth. Reserve money Granger causes price level movements in the period 1980:1-1995:12.

Bivariate causality from the price level to financial variables and interest rates is also shown in the data, and is quite significant. This is counterintuitive, as one would expect changes in financial variables to lead changes in the price level. The lack of a statistically significant causal relationship between the exchange rate and price level is worth emphasizing, in light of the relatively close movements of these two variables during the sample period (Table 1). The importance of the exchange rate variable is also supported by Odedokun (1997).

For the purpose of examining the causality between financial variables and the price level and, in particular, to shed further light in the relationship between the official exchange rate and the price level, we use multivariate Granger causality tests for three sample periods (Tables 5a, b, and c). In the full sample, the official exchange rate Granger causes movements in the price level when accompanied by other financial variables. One way to explain this is to argue that exchange rate movements impact the price level more through changes in other variables. For example, depreciation might be accommodated by a loosening of monetary policy, which then causes inflation to rise. The causal relation is statistically insignificant in the subsamples. Other results are broadly similar to the results

\footnotetext{
${ }^{9}$ Stationarity of economic time series is tested using the augmented Dickey-Fuller (ADF) and Phillips-Perron (PP) tests. Table 3 reports the test statistics with and without a trend. Based on the results, all variables exhibit stationarity in first-difference form and are integrated of order one (i.e., I(1)). Critical values are based on MacKinnon (1991).
} 
from bivariate analysis. However, narrow money significantly Granger-causes movements in the price level for the sample period up to end-1995. The causal correlations seem to break down during the estimation period starting in 1996:1. We return to this issue in Section IV.

To analyze the monetary transmission mechanism in Zimbabwe further, we estimate a vector autoregressive model comprising the price level, real GDP, and all financial variables used in the Granger causality tests to conduct variance decomposition analysis. This type of analysis can be useful in clarifying what percentage of the variance of the forecasted variable (price level) can be attributed to its own variance and that of other variables (Table 6). The results are consistent with the above results from Granger causality tests and indicate that currency in circulation plays a key role in determining the price level in the full sample.

The analysis for the full sample indicates that a lag, ranging from 6 to 12 months, exists for the impact from an initial shock to currency in circulation to the price level. ${ }^{10}$ Furthermore, the official exchange rate is significant in the vector autoregression, although its impact on the price level is small. The result also suggests that the pass-through effect from the exchange rate to the price level reaches its peak at 18 months after the initial shock in the full sample, at which point the exchange rate explains about 20 percent of the price level variance. This indicates partial exchange rate pass-through to domestic prices in Zimbabwe. ${ }^{11}$

During 1980:1 - 1995:12, the variance of reserve money becomes a significant determinant of price level variance, suggesting a possible role for it as a nominal anchor. Own variance is more persistent, which may be in part due to the relatively lower variance of inflation in this period (Table 1). During the high inflation period (1996:1-2001:12), own variance seems to dominate other sources of variance, except for the variance of deposit interest rate, which is relatively large. The reason for the dominance of own variance in this period could be due to high "noise" in price data (i.e., large standard error). Another possibility is that non-market mechanisms that were introduced by the authorities in recent years, such as widespread use of price controls and non-market clearing interest and exchange rates, and the rapid growth of informal activities, have weakened the relevance of official statistics to measure economic activity.

These results, in particular the apparent failure to obtain a significant monetary impact on the price level other than for currency in circulation, except for the earlier subperiod, are worth pointing out, given that other studies find a strong relationship between broad money and the price level. This could be due to the liberalization of Zimbabwe's financial markets in the

${ }^{10}$ The results are robust for alternative ordering of the variables. The roots of the polynomial are within the unit circle and hence the system is considered stable.

${ }^{11}$ Choudhri and Hakura (2001) report a greater long-term pass-through effect for Zimbabwe, about 35 percent, based on single-equation difference equation specification, which is close to the average for medium-inflation countries. 
early 1990s, which could have caused instability in monetary aggregates, similar to the experience of other developing countries (see Cottarelli and Giannini, 1997). As a result, money demand relations could have changed, eroding the usefulness of historical relations for monetary policy implementation.

While financial markets in Zimbabwe are somewhat developed and some financial deepening has taken place in the country, these developments are relatively recent (Gelbard and Leite, 1999). ${ }^{12}$ However, the demand for cash may be less affected by financial liberalization than the demand for other monetary aggregates since the demand for currency is associated with transaction demand, which is relatively stable relative to GDP. Changes in monetary policy, including in reserve requirement ratios, are also likely to have an impact on money demand. ${ }^{13}$

Furthermore, the volatility of broader monetary aggregates reflects measurement problems, for example arising from changes in the definition of the aggregates and changes in Zimbabwe's exchange controls (in particular, foreign currency deposits, which are part of broad money, have been subject to exchange control changes). Finally, interest rates have been negative in real terms, particularly before their liberalization in the early 1990s, thus making them less important for portfolio decisions.

Because of the lags involved in implementing monetary policy, an important consideration in choosing an operating target is the extent to which this target behaves as a leading indicator of inflation, which is the ultimate objective of monetary policy. We have provided evidence to suggest that currency in circulation is a more consistent predictor of future price movements than any other financial variable. However, the rapid acceleration of inflation in recent years has weakened this relationship. To examine further the role of monetary variables in determining the price level, we analyze whether a well-defined money demand function exists that can provide a basis for monetary policy to influence the price level.

\section{A Quest for a Nominal ANCHOR}

Is there a monetary variable that could serve as a nominal anchor, or can the exchange rate play that role? For this to be the case, two elements are needed. First, there needs to exist a well-defined long-term relationship between the price level and an anchor variable. Second, monetary policy needs to be credible and supported by other policies (fiscal, in particular). This paper focuses on the first issue.

12 Jenkins (1999) notes that financial repression was probably important for suppressing the demand for money and facilitating arbitrage, at least prior to financial market liberalization.

${ }^{13}$ Since 2001 the Reserve Bank of Zimbabwe has allowed banks to onlend a portion of their statutory reserve balances, thereby lowering the effective reserve requirements. 
Zimbabwe has experimented with exchange rate and monetary anchors in the past, but as we discussed earlier, these policies failed to provide guidance for price expectations. This is for the most part because these policies have lacked credibility and were not supported by other macroeconomic policies, in particular fiscal policy.

Studies by Jenkins (1999) and Nyawata (2001) report a well-identified relationship between monetary variables and the price level. However, empirical evidence to support an exchange rate anchor is more elusive. We will identify a money demand relationship using the Johansen and Juselius cointegration technique (Johansen and Juselius, 1990). This has the advantage that it is not necessary to specify the causal relations between variables ex ante; an indication of weak exogeneity can be inferred from the results (Wald tests).

Empirical models typically specify money demand in terms of real balances, implying price homogeneity, that is, unitary elasticity between the price level and monetary aggregate. This is because of the econometric problems associated with the use of nominal rather than real variables as the dependent variable. Furthermore, empirical research suggests that the demand is for real balances rather than for nominal balances. A generic form of money demand equation can be written as follows:

$M / P=\mathrm{f}(y, \mathbf{R})$

where the demand for real money balances, $M / P$, is a function of the chosen scale variable, $y$ (in this study, we use real GDP), and a vector $\mathbf{R}$ of other variables thought to be relevant for explaining the demand for money (e.g., the rate of return on other assets relative to money), were $M$ is the money aggregate and $P$ is the price level. ${ }^{14}$ The "own" interest rate influences money demand positively because a higher return on money increases incentives to hold this asset; interest rates on other assets affect money demand negatively through the substitution channel. Currency depreciation, by increasing the cost of holding local currency, will have a negative impact on money demand.

High inflation affects money demand adversely because it erodes the real value of money balances, particularly non-interest bearing. In money demand studies, inflation is often used as a proxy for the return to real assets. Sriram (2001) stresses that it is important to select the opportunity cost variables properly, as omitting any variables tends to bias income elasticity estimates. Jenkins (1999) also includes rationing variables for foreign exchange and credits, in order to help identify a stable money demand relation for Zimbabwe.

${ }^{14}$ Sriram (2001) provides a good survey of recent empirical money demand studies and how to interpret variables included in the money demand function. 


\section{A. Full-Sample Estimates}

The cointegration results for currency in circulation are reported in Tables 7 and 8 . Year-onyear changes in the price level and exchange rate performed better than monthly changes of these variables and are therefore used here. This may be because year-on-year inflation is less volatile and more likely to be used as a basis for inflation expectations by the public. ${ }^{15}$

Table 7 presents the relevant Johansen statistics, while the cointegrating vector for currency demand can be written as follows (including constant term): ${ }^{16}$

$$
\begin{gathered}
R C U R=5.533+0.9608 * R G D P+0.9373 * T D R A T E-1.2477 * \text { INFLATION } \\
(0.2114) \quad(0.3058) \\
-0.6586 * D E P R E C I A T I O N-0.0706 * \text { FININNOV } \\
(0.1154)
\end{gathered}
$$

The estimated long-run elasticity vis-à-vis real GDP is 0.96 and broadly in line with Sriram (2001) and Jenkins (1999), but higher that Nyawata (2001). The estimated income elasticity is statistically not different from unity and consistent with the transaction motive for holding money. The parameter estimate for the three-month deposit interest rate, which is statistically significant, is positive but contrary to expectations. Interest rates, for the most part, have not played an important role in allocating financial assets in Zimbabwe, as nominal interest rates remained virtually unchanged until their liberalization in the beginning of the $1990 \mathrm{~s}$ (Figure 4). ${ }^{17,18}$ Interest rates adjusted for inflation have frequently been negative. Furthermore, real currency holdings of the public generally rose after the end to the financial repression, which coincided with the rise in nominal interest rates.

Inflation has had a significant direct impact on currency demand. The parameter estimate for inflation has the expected negative sign, which suggests that the willingness to hold cash balances is negatively influenced by inflation. It is also evident in the negative parameter estimate for depreciation that currency substitution has a role to play in money demand.

15 Jenkins (1999) uses the year-on-year rate of currency depreciation as a measure of the expected return on foreign currency holdings.

${ }^{16}$ Estimated standard errors are reported in brackets.

${ }^{17}$ See also Jenkins (1999) for a discussion on nominal and real interest rates.

${ }^{18}$ Interest rates in Zimbabwe were liberalized only in the early 1990s and formal capital controls remain in place. However, exchange rate depreciation provides an incentive for capital flight. As shown below, the interest rate variable is not significant for the sample ending at end-1995. 
Financial innovation is associated with lower demand for currency, as would be expected, given that it is measured as the ratio of broad money to currency in circulation.

Table 8 a rejects the joint-test for normality of the estimated residuals, although skewness is not a major problem except for FININNOV (Figure 6). ${ }^{19}$ Non-normality leads to inefficient but unbiased and consistent estimators. ${ }^{20}$ The residual correlation matrix shows that all offdiagonal elements are close to zero (Table $8 b$ ).

Pairwise Granger-causality was examined using Wald tests (Table 9). ${ }^{21}$ The results suggest that currency demand can be treated as weakly exogenous vis-à-vis inflation. Inflation cannot be treated as weakly exogenous. ${ }^{22}$ Wald tests clarify the channels through which exchange rate changes could impact the domestic economy. This "chain of events" implies that currency depreciation influences inflation through the interest rate channel, which then affects the demand for currency. Changes in currency holdings impact inflation through the demand effect. It therefore offers evidence for the effectiveness of monetary policy to counter the inflationary effects of depreciation.

Figure 7 illustrates how shocks to currency demand, output, the interest rate, inflation, the exchange rate, and financial innovation affect inflation (measured by one standard deviation change in each variable). The results are consistent with the earlier discussion on factors that contribute to price level movements (Section III). Shocks to interest and exchange rates impact inflation with a lag, from 6 to 10 months (shorter for the exchange rate variable), and these effects are statistically significant. Both effects become weaker after about 12 to 14 months. A shock to currency demand, on the other hand, influences inflation with a lag of about 7 months, and remains significant for the entire sample period. This suggests that monetary policy aimed at currency demand can be effective in containing inflation. The "own price" effect is highly significant and persistent. Other variables do not exert significant influences on inflation.

We do not find well-identified demand functions for reserve, narrow and broad moneys. In this respect, our results are somewhat different from those of Jenkins (1999) and Nyawata (2001), which may be due to the use of higher-frequency data in this study and differences in the specification of variables. Regarding the latter, the variable used to measure the demand

${ }^{19}$ All unit roots of the VAR are within the unit circle. Joint test for heteroscedasticity of the estimated residuals is significant at the 1 percent marginal significance level. However, there is no significant autocorrelation in the estimated residuals.

${ }^{20}$ Kmenta (1986).

${ }^{21}$ These tests can be used for inference on weak exogeneity.

${ }^{22}$ This should be expected in an economy where the exchange rate is flexible. 
for currency in our study is currency in circulation, which comprises currency outside banks, a concept used by Jenkins, and bank holdings of cash in vault. Currency in circulation is readily available in the Reserve Bank of Zimbabwe's balance sheet and, hence, provides a basis for policy decisions; cash in vault, however, is reported less frequently and is typically estimated. Other variables in Jenkins' study, such as proxies for credit and foreign currency rationing, were unavailable to us. ${ }^{23}$ Furthermore, the sample period used in this study includes the recent acceleration in inflation, which is likely to have distorted the structural relations.

Regarding specific results, Jenkins fails to establish a long-run relationship between demand for currency and inflation (page 406 of Jenkins (1999)). Currency substitution, however, is significant in both Jenkins' and Nyawata's studies. Jenkins fails to identify a cointegrating relation for bank deposits, citing changes in the classification of bank deposits.

\section{B. Estimates for the Subperiod 1980:1-1995:12}

In light of our earlier discussion, there seems to be a strong case to suggest that parameter estimates may not be constant in time. To account for this possibility, we estimate equation (1) for currency in circulation covering two separate sample periods. The results for the period 1980:1 - 1995:12 are reported below, which indicate that the demand for currency reverts to a standard demand function (Table 10):

$R C U R=5.6952+0.9808 * R G D P-0.8328 * D E P R E C I A T I O N-0.0912 * F I N I N N O V$

$$
(0.1642) \quad(0.1534)
$$

where TDRATE and INFLATION drop out since their estimates are not statistically different from zero. The nonsignificant parameter estimate for the deposit interest rate reenforces the view that interest rates were not an important factor in the allocation of financial assets prior to the liberalization of bank interest rates.

The parameter estimates for RGDP, DEPRECIATION, and FININNOV remain more or less unchanged and highly significant. One possible explanation for the insignificance of the parameter estimate for INFLATION in this sample is that this variable captures the increase in inflation volatility over the past few years, which is not a factor in the current estimation. Tables $11 \mathrm{a}$ and $\mathrm{b}$ report residual diagnostics tests for VAR. Wald test statistics are provided in Table 12. Break-point F-tests, based on recursive estimation of the VAR for the period 1996:1-2001:12, indicate that the estimated parameters have not remained constant. ${ }^{24}$

\footnotetext{
${ }^{23}$ Jenkins uses proxies for foreign currency availability and government domestic borrowing.

${ }^{24}$ These tests are performed under the null hypothesis of constant parameter. The test statistic has an F-distribution, and is highly significant (it is related to the CUSUMSQ statistic).
} 
Regarding period 1996:1-2001:12, we are unable to establish a money demand relation for any monetary variable. Indeed, the statistical relations break down, which reflects the rapid rise in inflation and the accompanied distortions in the economy.

\section{Conclusions}

This study has analyzed the underlying determinants of prices in Zimbabwe using a wide range of statistical techniques. The results are robust to alternative specifications. The key results for the full sample are as follows. First, there is a strong linkage between currency in circulation and the price level. This suggests that currency in circulation would provide a good leading indicator of future price movements. Second, cointegration analysis establishes a well-identified long-run money-demand relation for currency in circulation, suggesting that this monetary aggregate could be helpful to the Reserve Bank of Zimbabwe as an intermediate monetary operating target. Third, reserve money, which the Reserve Bank of Zimbabwe has used as an intermediate policy target, is ineffective in the current highinflation environment, because the demand for reserve money is not welldefined, while its information content for predicting future price movements is weak. Fourth, well-defined money-demand functions for narrow and broad money cannot be establised in the full sample. ${ }^{25}$ Sixth, statistical relations seem to break down during the high-inflation period of the past few years. This raises serious challenges for monetary policy implementation, particularly regarding the appropriate anchor to facilitate disinflation in the Zimbabwean economy. $^{26}$

It has been argued that the exchange rate could serve as a nominal anchor in Zimbabwe. As experience has shown, however, pegging the exchange rate has not succeeded in constraining other - namely, monetary and fiscal policies - I therefore believe it has not been a credible policy anchor. This may in part explain its low information content for predicting future price movements. This study's analysis suggests that exchange rate changes have an impact on domestic prices through the currency-substitution channel and influence the demand for currency indirectly through the interest rate channel. The pass-through effect to domestic prices is only partial, which does not mean that exchange rate changes are insignificant. The Reserve Bank of Zimbabwe would be well advised, therefore, to counter inflationary effects arising from exchange rate changes with an appropriately tight monetary policy.

These results need to be interpreted with caution. Although the results appear to be robust for alternative model specifications and are consistent with other studies in this topic area, the estimated parameters are shown to be unstable owing to the rapid rise in inflation since the

${ }^{25}$ Kochhar (1996) provides an analysis for using alternative definitions of reserve money in the context of IMF-supported programs.

${ }^{26}$ See, for example, Eichengreen and others (1999) for a comprehensive discussion of the use of various nominal anchors and strategies during disinflation. 
late 1990s. It is possible, therefore, that once inflation has been brought down to a relatively low level, another monetary aggregate, such as reserve money, could become useful for the conduct of monetary policy. Nontheless, high inflation and the accompanying policies have undermined the stability of structural relations, for the reasons discussed earlier, and this is likely to complicate macroeconomic management in the future.

Finally, I wish to emphasize that economic policies are only effective if accompanied by credible and genuine commitment of the authorities. In the past, the credibility of monetary policy has been undermined by the lack of support from fiscal policy, as well as the lack of consistency in policy implementation. Strengthening the Reserve Bank of Zimbabwe's independence and clarifying its policy objectives should assist in enhancing its credibility. 


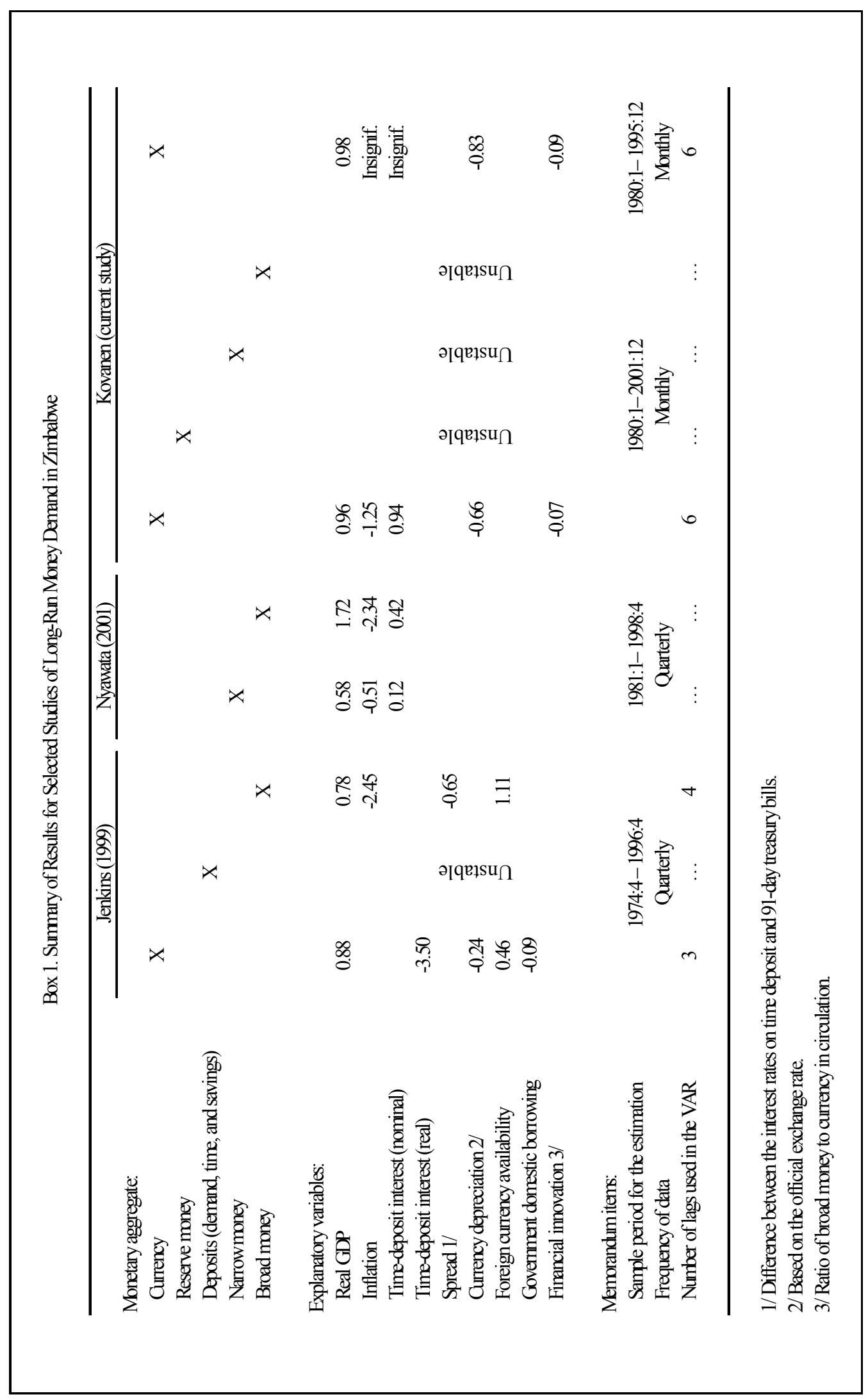


Table 1. Selected Features of Inflation, 1980:1-2003:12

(Annual percentage change)

\begin{tabular}{|c|c|c|c|}
\hline \multicolumn{3}{|c|}{ Inflation } & \multirow{2}{*}{$\begin{array}{l}\text { Change in the } \\
\text { exchange rate } 2 /\end{array}$} \\
\hline Period & Mean & Std. 1/ & \\
\hline Full sample & 39.65 & 81.76 & 34.48 \\
\hline \multicolumn{4}{|l|}{ Subperiods } \\
\hline 1980:1- 1989:12 & 12.86 & 6.26 & 12.91 \\
\hline 1990:1- 1999:12 & 29.36 & 13.02 & 32.58 \\
\hline $2000: 1-2003: 12$ & 187.96 & 151.32 & 115.76 \\
\hline 1980:1- 1995:12 & 17.87 & 9.72 & 17.78 \\
\hline 1996:1-2003:12 & 96.37 & 125.39 & 75.26 \\
\hline
\end{tabular}

1/ Standard deviation of annual inflation.

2/ Period average change (annualized). 
$-18-$

Table 2. Zimbabwe: Summary Statistics, 1980:1-2001:12

\begin{tabular}{|c|c|c|c|c|c|c|c|c|c|}
\hline & $\log (C P I)$ & $\log (C U R)$ & $\log (M 2)$ & $\log (M O N E Y)$ & $\log (R E S M)$ & $\log (R G D P)$ & TBRATE & TDRATE & FXRATE \\
\hline Mean & 3.849 & 6.877 & 9.191 & 8.145 & 7.417 & 9.911 & 19.488 & 18.298 & 1.419 \\
\hline Median & 3.476 & 6.732 & 8.922 & 7.767 & 7.133 & 9.938 & 9.650 & 14.000 & 0.968 \\
\hline Maximum & 7.091 & 10.214 & 12.385 & 11.749 & 10.852 & 10.192 & 69.410 & 54.000 & 4.009 \\
\hline Minimum & 2.079 & 4.827 & 6.877 & 6.147 & 5.186 & 9.517 & 3.050 & 3.500 & -0.466 \\
\hline Standard deviation & 1.300 & 1.289 & 1.454 & 1.530 & 1.462 & 0.187 & 15.800 & 11.771 & 1.358 \\
\hline Skewness & 0.572 & 0.594 & 0.380 & 0.592 & 0.503 & -0.193 & 1.476 & 1.138 & 0.455 \\
\hline Kurtosis & 2.337 & 2.442 & 1.979 & 2.136 & 2.190 & 1.901 & 4.821 & 3.758 & 2.073 \\
\hline Jarque-Bera & 19.210 & 18.953 & 17.817 & 23.629 & 18.336 & 14.915 & 132.307 & 63.272 & 18.555 \\
\hline Significance & 0.000 & 0.000 & 0.000 & 0.000 & 0.000 & 0.001 & 0.000 & 0.000 & 0.000 \\
\hline Sum & 1016.020 & 1815.616 & 2426.483 & 2150.165 & 1958.218 & 2616.383 & 5144.725 & 4830.740 & 374.544 \\
\hline Sum of squared deviations & 444.374 & 436.857 & 555.955 & 615.861 & 561.826 & 9.242 & 65657.420 & 36442.990 & 484.926 \\
\hline
\end{tabular}


Table 3. Zimbabwe: Unit-Root Tests, 1980:1-2001:12 1/ (1980:1-2001:12)

\begin{tabular}{|c|c|c|c|c|c|c|c|}
\hline \multirow[b]{2}{*}{ Variable } & \multicolumn{3}{|c|}{ Augmented Dickey-Fuller } & \multicolumn{4}{|c|}{ Phillips-Perron } \\
\hline & With trend & Without trend & & With trend & & Without trend & \\
\hline$C P I$ & 4.142 & 6.430 & & 4.152 & & 6.791 & \\
\hline$D(C P I)=$ Inflation & $-5.718 * *$ & -4.173 & $* *$ & -11.543 & $* *$ & -9.867 & ** \\
\hline$D$ (Inflation) & $-10.071 * *$ & -10.168 & $* *$ & -62.123 & $* *$ & -59.881 & $* *$ \\
\hline CUR & 4.753 & 3.811 & & 3.808 & & 4.075 & \\
\hline$D(C U R)$ & $-8.489 * *$ & -3.214 & $*$ & -15.874 & $* *$ & -15.532 & $* *$ \\
\hline$D D \log (C U R)$ & $-8.810 * *$ & -8.702 & & & & & \\
\hline$R C U R$ & $-4.090 * *$ & -4.060 & $* *$ & -3.407 & $*$ & -3.349 & * \\
\hline$D(R C U R)$ & $-16.796 * *$ & -16.791 & $* *$ & -17.248 & $* *$ & -17.246 & $* *$ \\
\hline$R E S M$ & 1.726 & 3.555 & & 0.878 & & 3.047 & \\
\hline$D(R E S M)$ & $-7.949 * *$ & -7.193 & $* *$ & -20.992 & $* *$ & -20.200 & $* *$ \\
\hline RRESM & -3.299 & -2.229 & & -4.394 & $* *$ & -2.510 & \\
\hline$D(R R E S M)$ & $-8.050 * *$ & -8.049 & $* *$ & -20.880 & $* *$ & -20.879 & $* *$ \\
\hline MONEY & 1.124 & 4.043 & & 1.063 & & 4.837 & \\
\hline$D(M O N E Y)$ & $-7.788 * *$ & -6.473 & $* *$ & -21.748 & $* *$ & -20.167 & $* *$ \\
\hline DDLog(Money) & $-11.730 * *$ & -11.740 & & & & & \\
\hline RMONEY & -2.226 & -1.064 & & -2.388 & & -1.045 & \\
\hline$D(R M O N E Y)$ & $-7.776 * *$ & -7.788 & $* *$ & -20.547 & $* *$ & -20.568 & $* *$ \\
\hline$M 2$ & -0.087 & 2.948 & & -1.193 & & 1.293 & \\
\hline$D(M 2)$ & $-7.834 * *$ & -7.140 & $* *$ & -30.427 & $* *$ & -29.310 & $* *$ \\
\hline$R M 2$ & -1.879 & -1.769 & & -4.167 & $* *$ & -3.449 & * \\
\hline$D(R M 2)$ & $-7.130 * *$ & -7.109 & $* *$ & -28.123 & $* *$ & -27.943 & $* *$ \\
\hline TBRATE & $-3.595 *$ & -2.237 & & -2.802 & & -1.949 & \\
\hline$D(T B R A T E)$ & $-5.456 * *$ & -5.473 & $* *$ & -8.696 & $* *$ & -8.717 & $* *$ \\
\hline TDRATE & -3.184 & -2.496 & & -2.288 & & -2.091 & \\
\hline$D(T D R A T E$ & $-5.006 * *$ & -4.993 & $* *$ & -11.677 & $* *$ & -11.674 & $* *$ \\
\hline FXRATE & -2.149 & 1.014 & & -1.999 & & 1.318 & \\
\hline$D(F X R A T E$ & $-6.721 * *$ & -6.533 & $* *$ & -10.913 & $* *$ & -10.813 & $* *$ \\
\hline$R G D P$ & -1.392 & -2.588 & & -1.378 & & -2.627 & \\
\hline$D(R G D P)$ & $-7.110 * *$ & -6.723 & $* *$ & -18.064 & $* *$ & -17.703 & $* *$ \\
\hline
\end{tabular}

Notes: $*$ denotes acceptance of the null hypothesis of stationarity at 5 percent significance level.

** denotes acceptance the null hypothesis of stationarity at 1 percent significance level.

For any variable $X, D(X)$ is defined as $X(t)-X(t-1)$.

1/ Constant has been included in the estimations. 


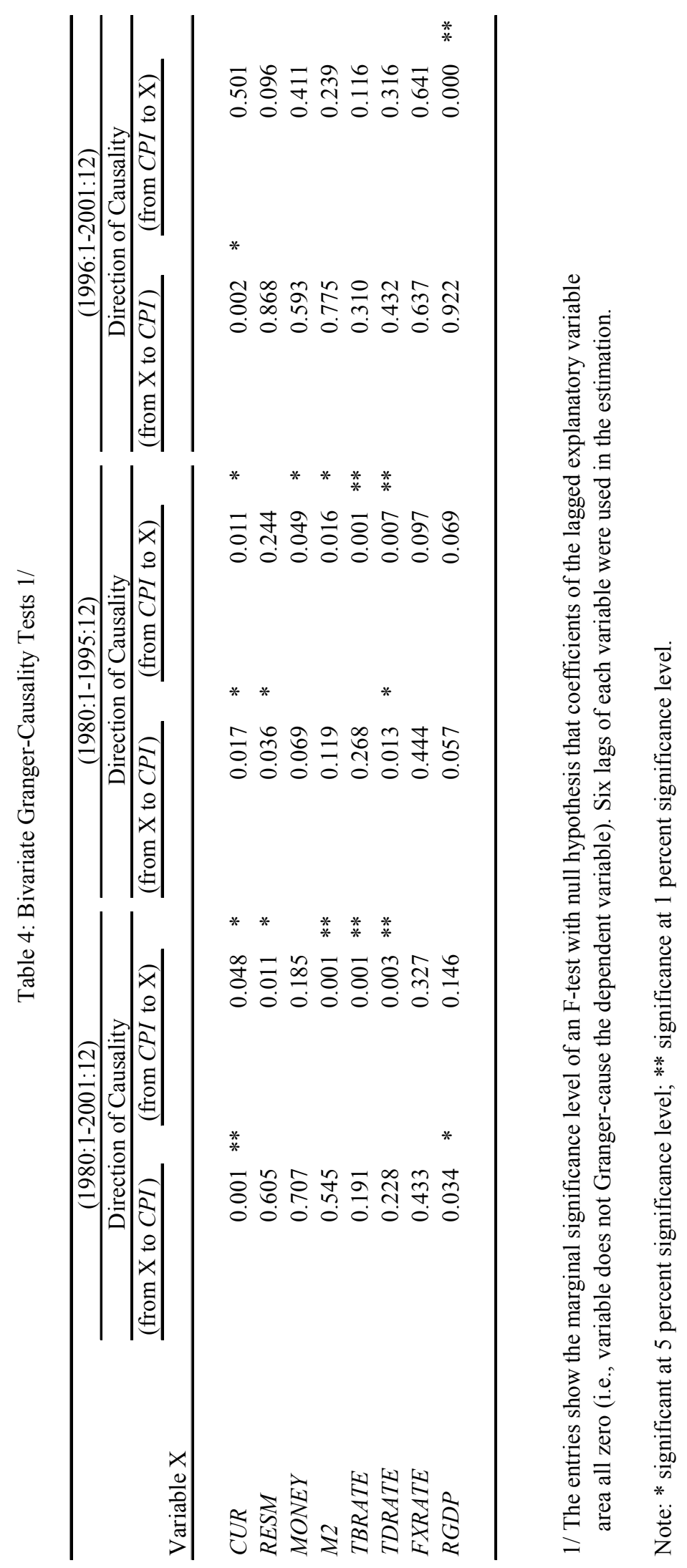


Table 5a: Multivariate Granger-Causality Tests, 1980:1-2001:12 1/

\begin{tabular}{|c|c|c|c|c|c|c|c|c|c|c|c|c|}
\hline \multirow[b]{2}{*}{ Variable } & \multicolumn{12}{|c|}{ Marginal Significance Level } \\
\hline & Model (1) & & Model (2) & & Model (3) & & Model (4) & & Model (5) & & Model (6) & \\
\hline CUR & 0.000 & $* *$ & $\ldots$ & & $\ldots$ & & $\ldots$ & & $\ldots$ & & $\ldots$ & \\
\hline RESM & $\ldots$ & & 0.148 & & $\ldots$ & & $\ldots$ & & $\ldots$ & & $\ldots$ & \\
\hline MONEY & $\ldots$ & & $\ldots$ & & 0.609 & & $\ldots$ & & $\ldots$ & & $\ldots$ & \\
\hline$M 2$ & $\ldots$ & & $\ldots$ & & $\ldots$ & & 0.579 & & $\ldots$ & & $\ldots$ & \\
\hline TDRATE & 0.294 & & 0.020 & $*$ & 0.053 & & 0.048 & $*$ & 0.017 & $*$ & $\ldots$ & \\
\hline FXRATE & 0.017 & * & 0.021 & $*$ & 0.036 & $*$ & 0.021 & $*$ & 0.032 & $*$ & 0.157 & \\
\hline$R G D P$ & 0.000 & $* *$ & 0.000 & $* *$ & 0.001 & $* *$ & 0.014 & $*$ & 0.002 & ** & 0.008 & $* *$ \\
\hline
\end{tabular}

Table 5b: Multivariate Granger-Causality Tests, 1980:1-1995:12 1/

\begin{tabular}{|c|c|c|c|c|c|c|c|c|c|c|}
\hline \multirow[b]{2}{*}{$\underline{\text { Variable }}$} & \multicolumn{10}{|c|}{ Marginal Significance Level } \\
\hline & Model (1) & & Model (2) & Model (3) & & Model (4) & & Model (5) & & $\operatorname{Model}(6)$ \\
\hline CUR & 0.007 & $* *$ & $\ldots$ & $\ldots$ & & $\ldots$ & & .. & & ... \\
\hline RESM & $\ldots$ & & 0.371 & $\ldots$ & & $\ldots$ & & $\ldots$ & & $\ldots$ \\
\hline MONEY & $\ldots$ & & $\cdots$ & 0.035 & $*$ & $\ldots$ & & $\ldots$ & & $\ldots$ \\
\hline$M 2$ & $\ldots$ & & $\ldots$ & $\ldots$ & & 0.097 & & $\ldots$ & & $\ldots$ \\
\hline TDRATE & 0.051 & & 0.080 & 0.011 & $*$ & 0.019 & $*$ & 0.029 & $*$ & $\ldots$ \\
\hline FXRATE & 0.085 & & 0.476 & 0.394 & & 0.241 & & 0.684 & & 0.621 \\
\hline$R G D P$ & 0.321 & & 0.753 & 0.144 & & 0.418 & & 0.248 & & 0.198 \\
\hline
\end{tabular}

Table 5c: Multivariate Granger-Causality Tests, 1996:1-2001:12 1/

\begin{tabular}{|c|c|c|c|c|c|c|}
\hline \multirow[b]{2}{*}{ Variable } & \multicolumn{6}{|c|}{ Marginal Significance Level } \\
\hline & Model (1) & Model (2) & Model (3) & Model (4) & Model (5) & Model(6) \\
\hline$C U R$ & 0.110 & $\ldots$ & $\cdots$ & $\ldots$ & $\cdots$ & $\cdots$ \\
\hline RESM & $\ldots$ & 0.844 & $\ldots$ & $\ldots$ & $\ldots$ & $\ldots$ \\
\hline MONEY & $\ldots$ & $\ldots$ & 0.965 & $\ldots$ & $\ldots$ & $\ldots$ \\
\hline$M 2$ & $\ldots$ & $\ldots$ & $\ldots$ & 0.838 & $\ldots$ & $\ldots$ \\
\hline TDRATE & 0.933 & 0.472 & 0.636 & 0.411 & 0.153 & $\ldots$ \\
\hline FXRATE & 0.205 & 0.105 & 0.178 & 0.139 & 0.088 & 0.315 \\
\hline$R G D P$ & 0.646 & 0.484 & 0.564 & 0.550 & 0.515 & 0.548 \\
\hline
\end{tabular}

Notes: * denotes acceptance of the null hypothesis of stationarity at 5 percent significance level.

** denotes acceptance the null hypothesis of stationarity at 1 percent significance level.

1/ The entries show the marginal significance level of an F-test for omitting six lags of a single financial variable from an unrestricted ordinary least square equation that also includes a constant, six lags of the forecasted variable, and six lags of real GDP. The dependent variable is $C P I$. 


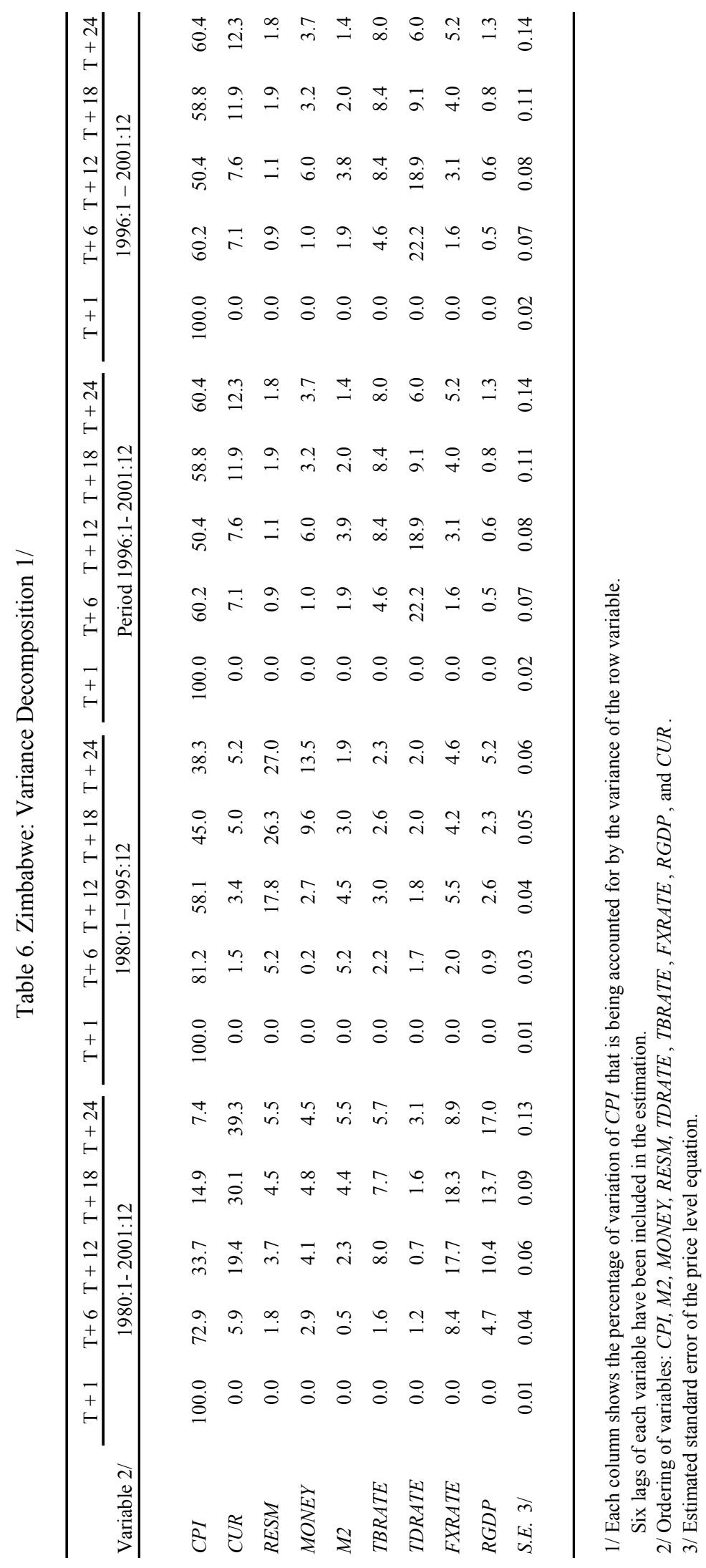


Table 7. Unrestricted Cointegration Estimates for Currency in Circulation, 1980:1-2001:12 1/

\begin{tabular}{lcccc}
\hline $\begin{array}{l}\text { Hypothesized } \\
\text { No. of CE(s) 1/ }\end{array}$ & Eigenvalue & $\begin{array}{c}\text { Trace } \\
\text { Statistic }\end{array}$ & $\begin{array}{c}\text { 5 Percent } \\
\text { Critical Value }\end{array}$ & $\begin{array}{c}1 \text { Percent } \\
\text { Critical Value }\end{array}$ \\
\hline & & & & \\
None ** & 0.176 & 111.958 & 94.150 & 103.180 \\
At most 1 & 0.088 & 62.202 & 68.520 & 76.070 \\
At most 2 & 0.072 & 38.513 & 47.210 & 54.460 \\
At most 3 & 0.047 & 19.233 & 29.680 & 35.650 \\
At most 4 & 0.024 & 6.945 & 15.410 & 20.040 \\
At most 5 & 0.003 & 0.788 & 3.760 & 6.650 \\
& & & & \\
\hline
\end{tabular}

\begin{tabular}{|c|c|c|c|c|}
\hline $\begin{array}{l}\text { Hypothesized } \\
\text { No. of CE(s) } 1 /\end{array}$ & Eigenvalue & $\begin{array}{l}\text { Max-Eigen } \\
\text { Statistic }\end{array}$ & $\begin{array}{c}5 \text { Percent } \\
\text { Critical Value }\end{array}$ & $\begin{array}{c}1 \text { Percent } \\
\text { Critical Value }\end{array}$ \\
\hline None ** & 0.176 & 49.756 & 39.370 & 45.100 \\
\hline At most 1 & 0.088 & 23.689 & 33.460 & 38.770 \\
\hline At most 2 & 0.072 & 19.280 & 27.070 & 32.240 \\
\hline At most 3 & 0.047 & 12.288 & 20.970 & 25.520 \\
\hline At most 4 & 0.024 & 6.157 & 14.070 & 18.630 \\
\hline At most 5 & 0.003 & 0.788 & 3.760 & 6.650 \\
\hline
\end{tabular}

Value of log-likelihood function:

Normalized cointegrating coefficients (std. errors below)

\begin{tabular}{cccccc}
\hline RCUR & RGDP & TDRATE & INFLATION & DEPRECIATION & FININNOV \\
\hline 1.0000 & -0.9608 & -0.9373 & 1.2477 & 0.6586 & 0.0706 \\
& 0.2114 & 0.3058 & 0.2949 & 0.1154 & 0.0130
\end{tabular}

Adjustment coefficients (std. errors below)

\begin{tabular}{cccccc}
\hline$D($ RCUR $)$ & $D(R G D P)$ & $D($ TDRATE $)$ & $D($ INFLATION $)$ & $D(D E P R E C I A T I O N)$ & $D($ FININNOV $)$ \\
\hline 0.0160 & -0.0039 & 0.0414 & 0.0459 & -0.0846 & -1.6214 \\
1.8165 & 0.0101 & 0.0108 & 0.0135 & 0.0341 & 0.5062 \\
\hline
\end{tabular}

Notes: $*(* *)$ denotes rejection of the hypothesis at the 5 percent (1 percent) level

Trace test indicates 1 cointegrating equation(s) at both 5 percent and 1 percent levels

1/ CE(s) stands for cointegrating equation(s). Df stands for degrees of freedom. 
Table 8a. Currency in Circulation: Test for Normality of the Residuals, 1980:1-2001:12

\begin{tabular}{lrrrrrr}
\hline Variable & Skewness & Prob. & Kurtosis & Prob. & Jarque-Bera & Prob. \\
\hline & & & & & & \\
RCUR & 0.14 & 0.37 & 3.51 & 0.09 & 3.64 & 0.16 \\
RGDP & 0.20 & 0.20 & 24.36 & 0.00 & $4,904.69$ & 0.00 \\
TDRATE & -0.25 & 0.11 & 5.12 & 0.00 & 51.12 & 0.00 \\
INFLATION & -0.22 & 0.14 & 3.23 & 0.46 & 2.72 & 0.26 \\
DEPRECIATION & 0.08 & 0.58 & 4.62 & 0.00 & 28.43 & 0.00 \\
FININNOV & 0.40 & 0.01 & 3.63 & 0.04 & 11.24 & 0.00 \\
& & & & & & \\
Joint & & 0.02 & & 0.00 & & 0.00 \\
\hline
\end{tabular}

Notes: "Prob." denotes probability. 
Table 8b. Residual Correlation Matrix, 1980:1-2001:12

\begin{tabular}{lcccccc}
\hline & RCUR & RGDP & TDRATE & INFLATION & DEPRECIATION & FININNOV \\
\hline & & & & & & \\
RCUR & 1.000 & -0.065 & -0.032 & -0.348 & 0.067 & -0.321 \\
RGDP & -0.065 & 1.000 & 0.020 & 0.056 & 0.079 & 0.160 \\
TDRATE & -0.032 & 0.020 & 1.000 & 0.025 & 0.041 & 0.080 \\
INFLATION & -0.348 & 0.056 & 0.025 & 1.000 & 0.004 & 0.053 \\
DEPRECIATION & 0.067 & 0.079 & 0.041 & 0.004 & 1.000 & -0.019 \\
FININNOV & -0.321 & 0.160 & 0.080 & 0.053 & -0.019 & 1.000 \\
\hline
\end{tabular}


Table 9. Pairwise Granger Causality/Block Exogeneity Wald Tests, 1980:1-2001:12 (Probability)

\begin{tabular}{lrrrrrr}
\hline & \multicolumn{7}{c}{ Dependent Variable } \\
\cline { 2 - 7 } & RCUR & RGDP & TDRATE & INFLATION & DEPRECIATION & FININNOV \\
\hline RCUR & $\ldots$ & 0.89 & 0.33 & 0.01 & 0.54 & 0.00 \\
RGDP & 0.19 & $\ldots$ & 0.64 & 0.26 & 0.44 & 0.04 \\
TDRATE & 0.03 & 0.94 & $\ldots$ & 0.89 & 0.22 & 0.83 \\
INFLATION & 0.30 & 0.65 & 0.12 & $\ldots$ & 0.22 & 0.00 \\
DEPRECIATION & 0.61 & 0.73 & 0.00 & 0.19 & $\ldots$ & 0.52 \\
FININNOV & 0.69 & 0.54 & 0.72 & 0.54 & 0.45 & $\ldots$ \\
\hline
\end{tabular}


Table 10. Unrestricted Cointegration Estimates for Currency in Circulation, 1980:1 - 1995:12 1/

\begin{tabular}{|c|c|c|c|c|}
\hline $\begin{array}{l}\text { Hypothesized } \\
\text { No. of CE(s) } 1 /\end{array}$ & Eigenvalue & $\begin{array}{c}\text { Trace } \\
\text { Statistic }\end{array}$ & $\begin{array}{c}5 \text { Percent } \\
\text { Critical Value }\end{array}$ & $\begin{array}{c}1 \text { Percent } \\
\text { Critical Value }\end{array}$ \\
\hline None ** & 0.235 & 105.056 & 94.150 & 103.180 \\
\hline At most 1 & 0.120 & 55.518 & 68.520 & 76.070 \\
\hline At most 2 & 0.084 & 31.846 & 47.210 & 54.460 \\
\hline At most 3 & 0.055 & 15.573 & 29.680 & 35.650 \\
\hline At most 4 & 0.025 & 5.198 & 15.410 & 20.040 \\
\hline At most 5 & 0.003 & 0.560 & 3.760 & 6.650 \\
\hline Hypothesized & & Max-Eigen & 5 Percent & 1 Percent \\
\hline No. of CE(s) $1 /$ & Eigenvalue & Statistic & Critical Value & Critical Value \\
\hline None ** & 0.235 & 49.538 & 39.370 & 45.100 \\
\hline At most 1 & 0.120 & 23.672 & 33.460 & 38.770 \\
\hline At most 2 & 0.084 & 16.273 & 27.070 & 32.240 \\
\hline At most 3 & 0.055 & 10.375 & 20.970 & 25.520 \\
\hline At most 4 & 0.025 & 4.638 & 14.070 & 18.630 \\
\hline At most 5 & 0.003 & 0.560 & 3.760 & 6.650 \\
\hline
\end{tabular}

Value of log-likelihood function:

$-302.80$

Normalized cointegrating coefficients (std. errors below)

\begin{tabular}{cccccc}
\hline RCUR & RGDP & TDRATE & INFLATION & DEPRECIATION & FININNOV \\
\hline 1.0000 & -0.9808 & -0.3473 & -0.2632 & 0.8328 & 0.0912 \\
& 0.1642 & 0.3393 & 0.3695 & 0.1534 & 0.0136
\end{tabular}

Adjustment coefficients (std. errors below)

\begin{tabular}{cccccc}
\hline$D(R C U R)$ & $D(R G D P)$ & $D(T D R A T E)$ & $D(I N F L A T I O N)$ & $D(D E P R E C I A T I O N)$ & $D($ FININNOV $)$ \\
\hline-0.0503 & 0.0101 & 0.0234 & 0.0979 & -0.0966 & -1.0186 \\
0.0241 & 0.0128 & 0.0109 & 0.0174 & 0.0391 & 0.7664 \\
\hline
\end{tabular}

Notes: $*(* *)$ denotes rejection of the hypothesis at the 5 percent (1 percent) level

Trace test indicates 1 cointegrating equation(s) at both 5 percent and 1 percent levels

1/ CE(s) stands for cointegrating equation(s). Df stands for degrees of freedom. 
Table 11a. Currency in Circulation: Test for Normality of the Residuals, 1980:1-1995:12

\begin{tabular}{|c|c|c|c|c|c|c|}
\hline Variable & Skewness & Prob. & Kurtosis & Prob. & Jarque-Bera & Prob. \\
\hline RCUR & -0.15 & 0.41 & 2.41 & 0.10 & 3.40 & 0.18 \\
\hline$R G D P$ & -0.41 & 0.02 & 15.65 & 0.00 & 1246.05 & 0.00 \\
\hline TDRATE & -0.34 & 0.06 & 4.75 & 0.00 & 27.28 & 0.00 \\
\hline INFLATION & -0.23 & 0.20 & 2.87 & 0.71 & 1.78 & 0.41 \\
\hline DEPRECIATION & 0.14 & 0.44 & 3.96 & 0.01 & 7.67 & 0.02 \\
\hline FININNOV & 0.36 & 0.05 & 2.90 & 0.79 & 3.99 & 0.14 \\
\hline Joint & & 0.02 & & 0.00 & & 0.00 \\
\hline
\end{tabular}

Note: "Prob" denotes probability. 
Table 11b. Residual Correlation Matrix, 1980:1-1995:12

\begin{tabular}{lrrrrrr}
\hline & RCUR & RGDP & TDRATE & INFLATION & DEPRECIATION & FININNOV \\
\hline RCUR & & & & & & \\
RGDP & 1.000 & -0.095 & -0.128 & -0.396 & 0.022 & -0.227 \\
TDRATE & -0.095 & 1.000 & 0.017 & 0.050 & 0.057 & 0.232 \\
INFLATION & -0.128 & 0.017 & 1.000 & 0.184 & 0.018 & 0.166 \\
DEPRECIATION & -0.396 & 0.050 & 0.184 & 1.000 & -0.011 & 0.024 \\
FININNOV & 0.022 & 0.057 & 0.018 & -0.011 & 1.000 & 0.008 \\
\hline
\end{tabular}


Table 12. Pairwise Granger Causality/Block Exogeneity Wald Tests, 1980:1-1995:12 (Probability)

\begin{tabular}{lrrrrrr}
\hline & \multicolumn{7}{c}{ Dependent Variable } \\
\cline { 2 - 7 } & RCUR & RGDP & TDRATE & INFLATION & DEPRECIATION & FININNOV \\
\hline RCUR & & & & & & \\
RGDP & $\ldots$ & 0.62 & 0.53 & 0.01 & 0.11 & 0.01 \\
TDRATE & 0.27 & $\ldots$ & 0.09 & 0.10 & 0.77 & 0.11 \\
INFLATION & 0.15 & 0.14 & $\ldots$ & 0.24 & 0.56 & 0.34 \\
DEPRECIATION & 0.45 & 0.41 & 0.09 & $\ldots$ & 0.51 & 0.14 \\
FININNOV & 0.27 & 0.09 & 0.07 & 0.33 & $\ldots$ & 0.78 \\
& 0.67 & 0.51 & 0.15 & 0.16 & 0.49 & $\ldots$ \\
\hline
\end{tabular}


Figure 1: Consumer Price Inflation (1980:1-2003:12)

(Percent; y ear-on-year)

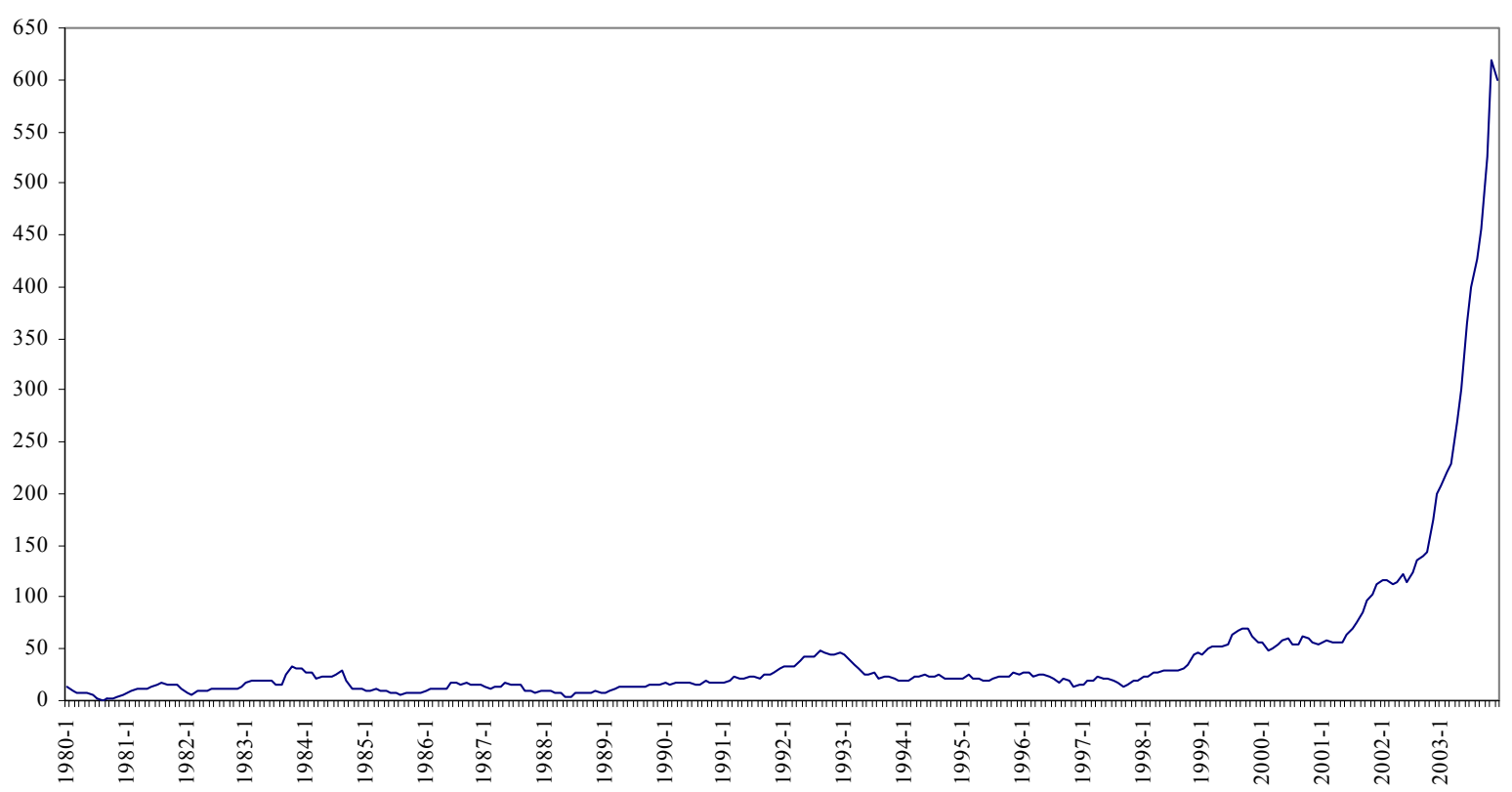


Figure 2: Inflation and Output Growth (1981-2002)

(Annual percentage change)

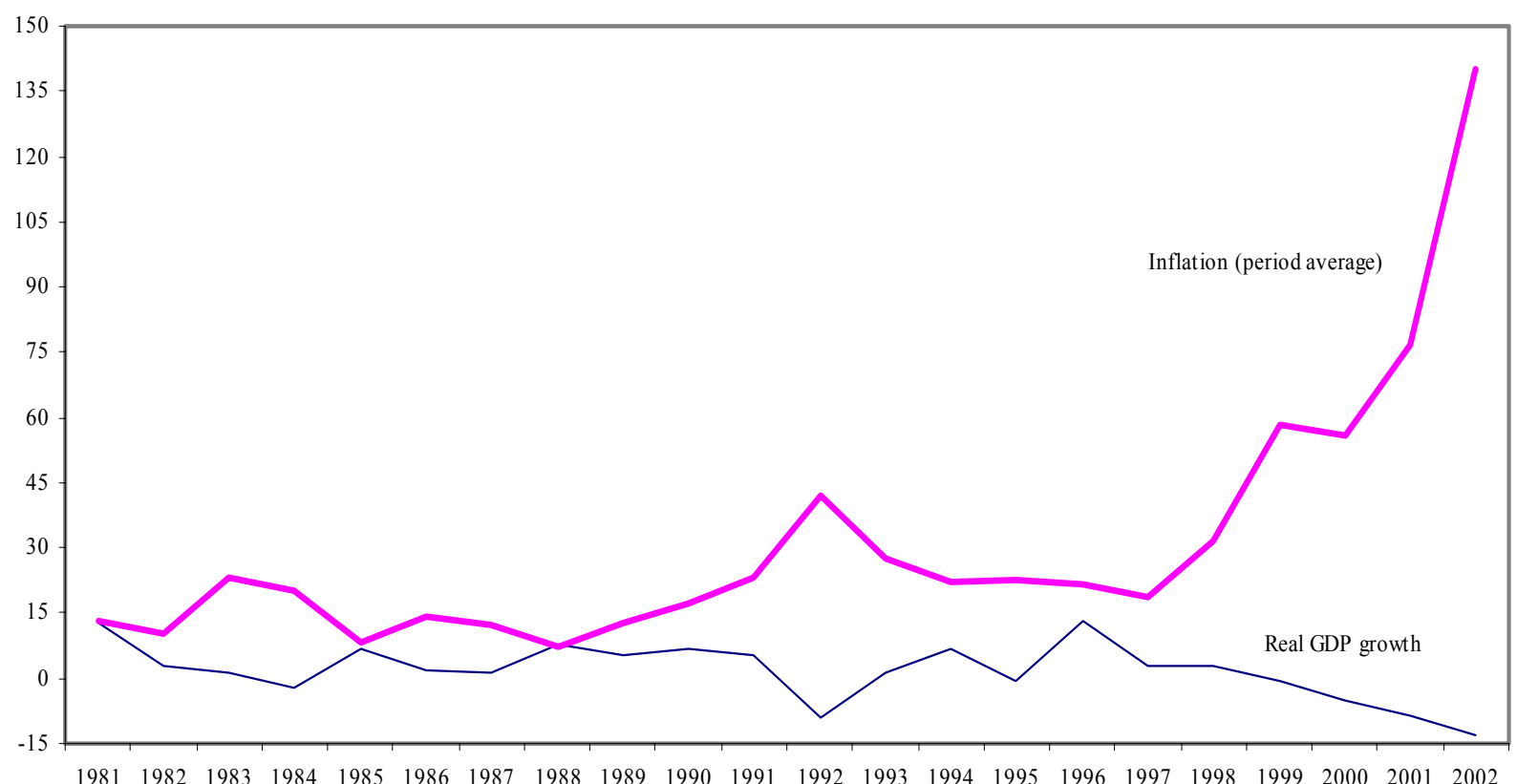


Figure 3: Financial Intermediation and Interest Rates (1980-2002)

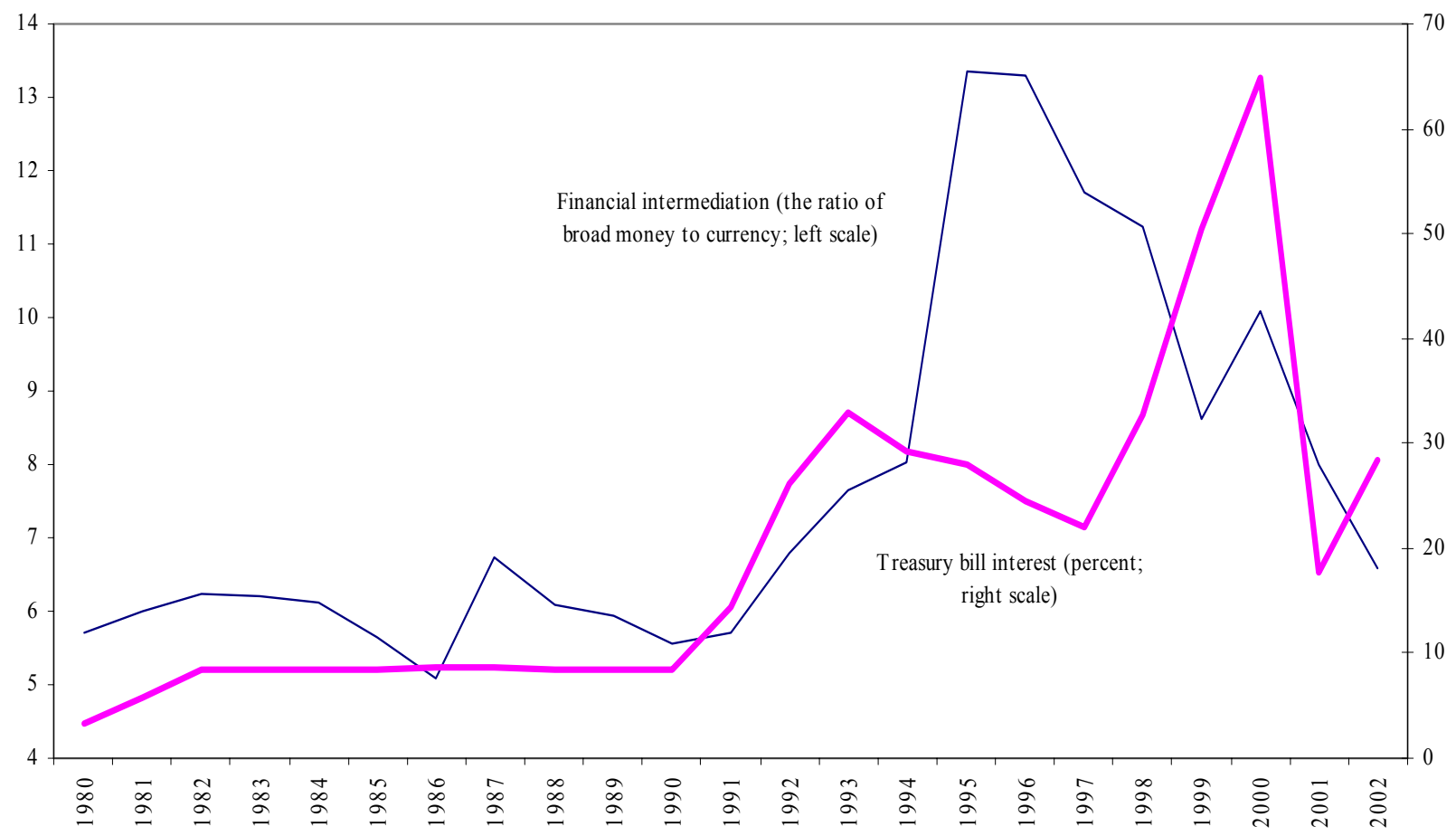


Figure 4: Treasury Bill and Three-Month Bank Deposit Interest Rates (1980:1-2003:10) (Annual percent)

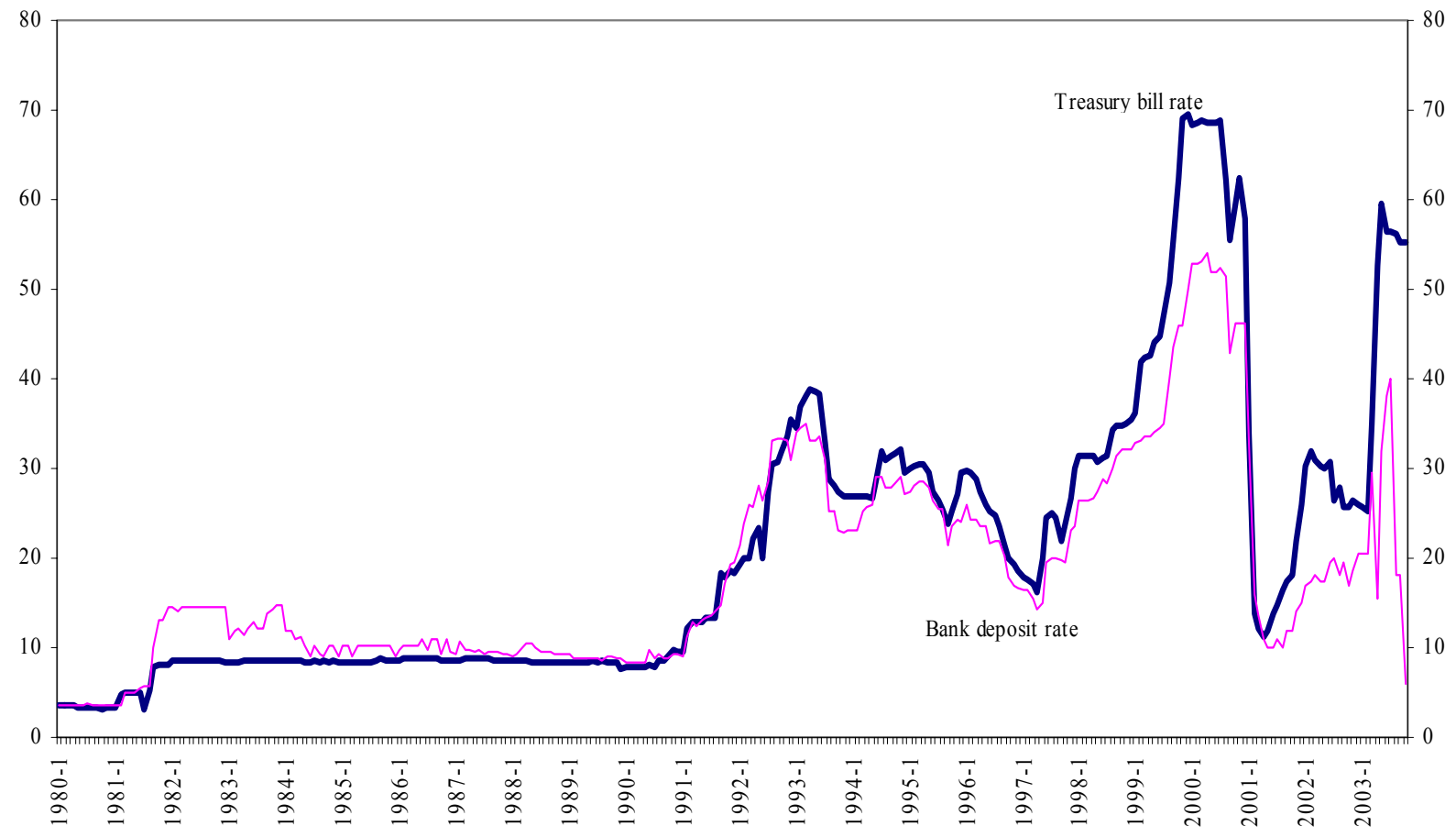


Figure 5. Zimbabwe: Real GDP and Manufacturing Output, 1975-2002 (Annual percentage change)

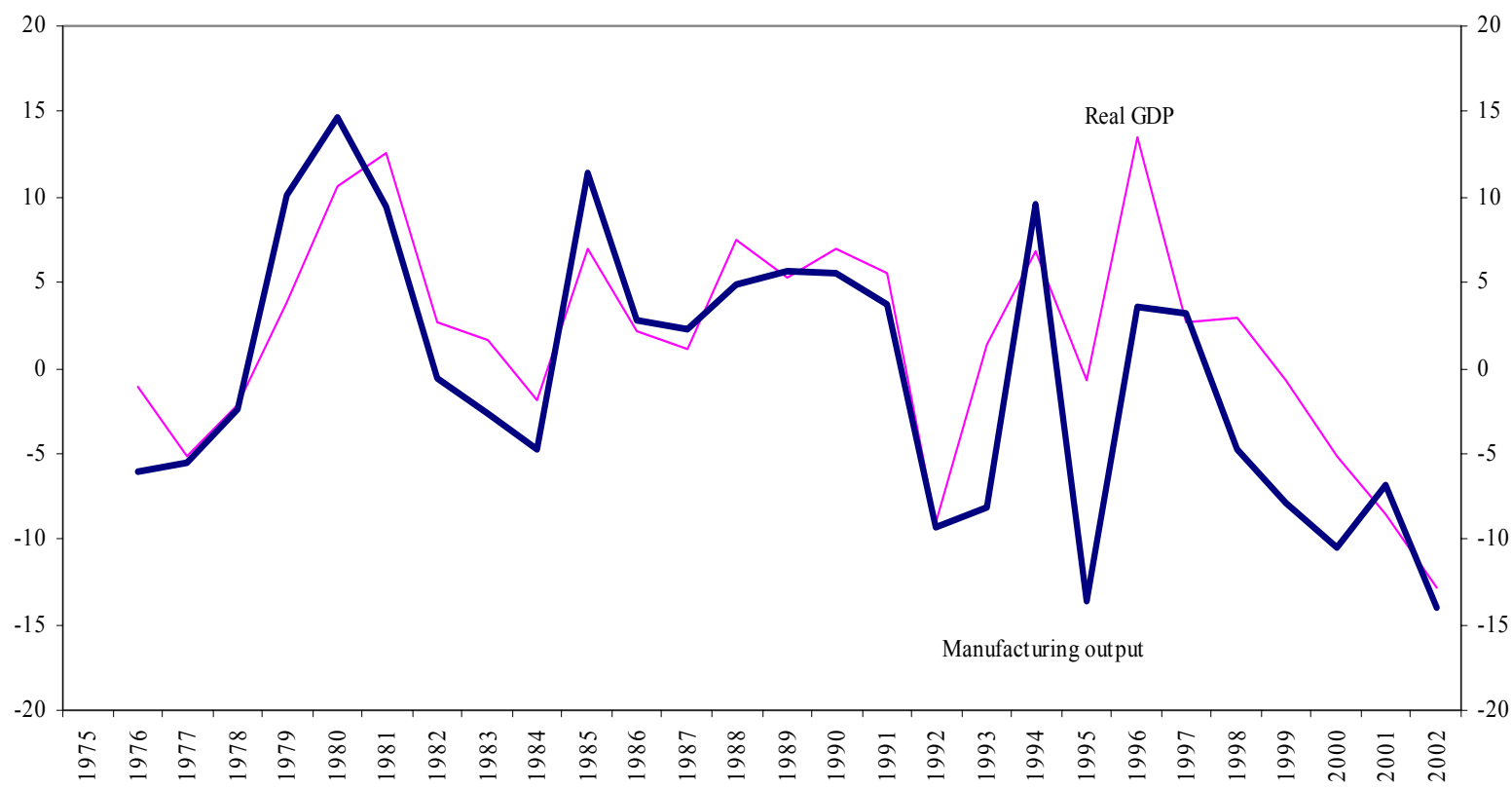


Figure 6. Residuals from VAR, 1980:1 - 2001:12
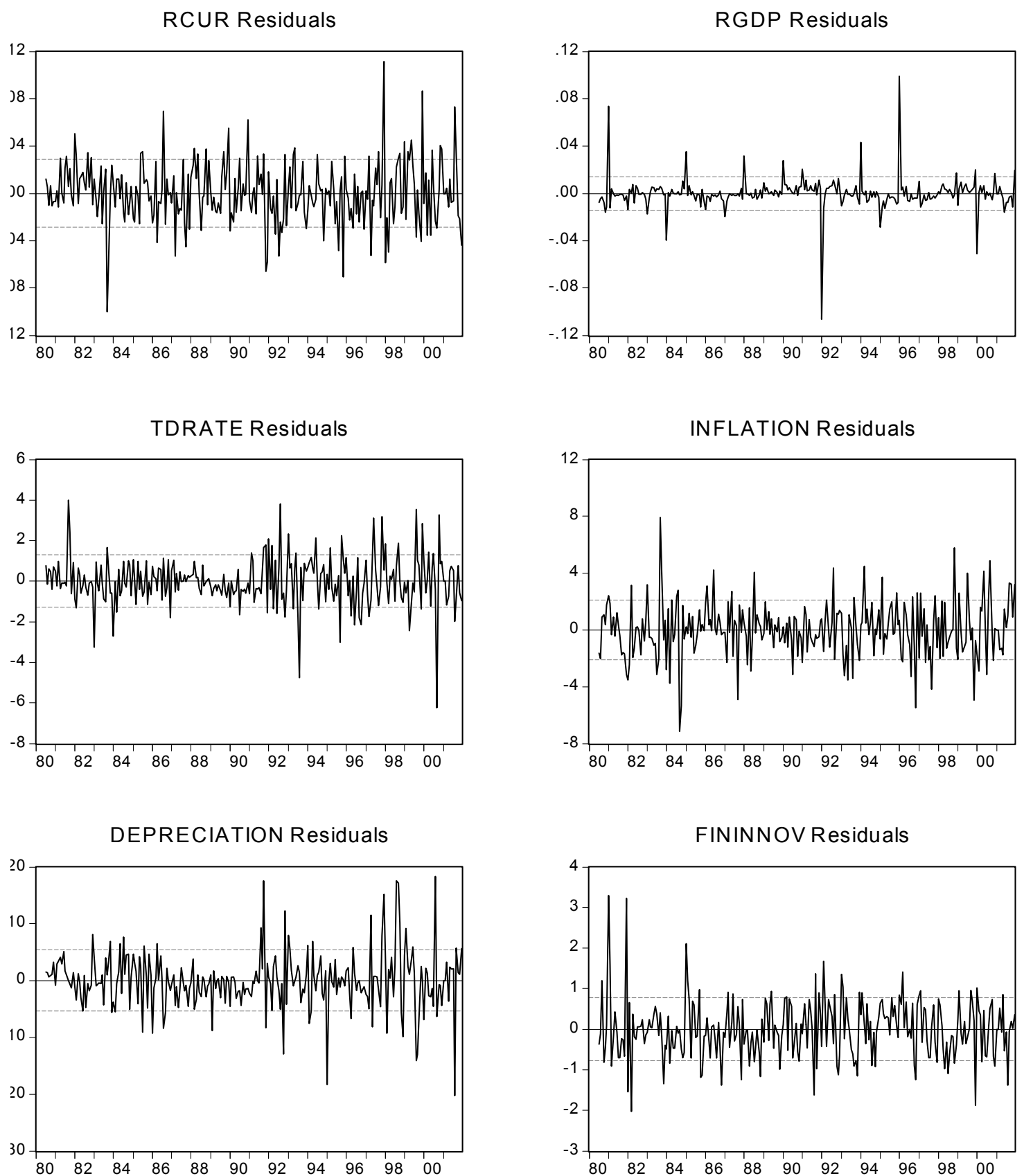


\section{Figure 7. Responses of Inflation to Innovation 1/}

Response to Nonfactorized One S.D. Innovations \pm 2 S.E.

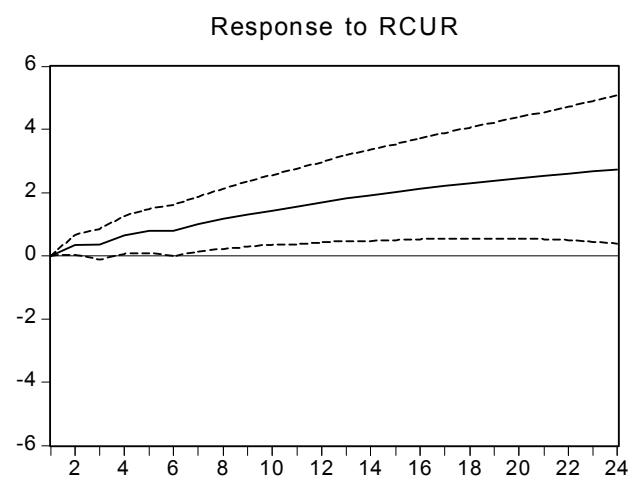

Response to RGDP

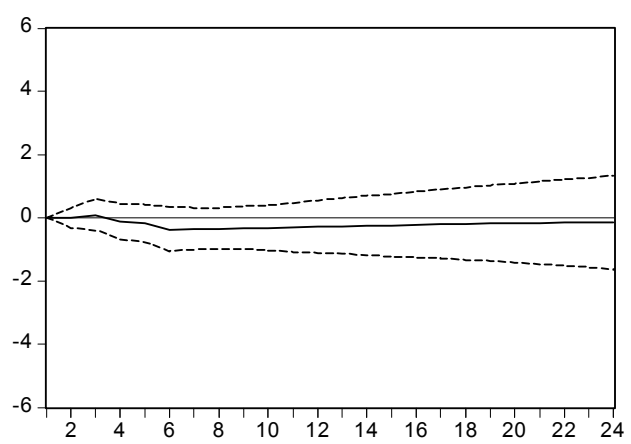

Response to TDRATE

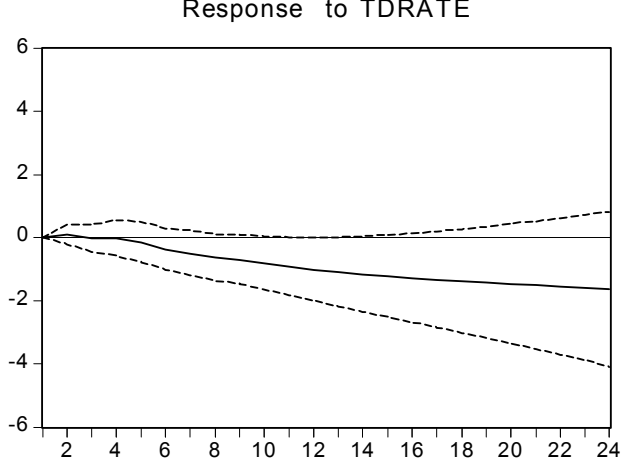

Response to INFLATION

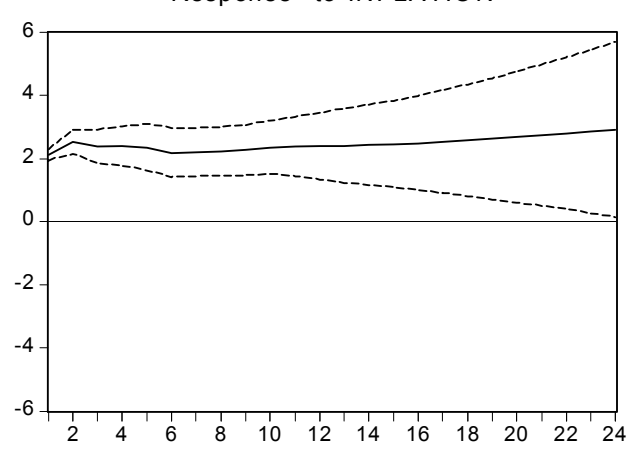

Response to DEPRECIATION

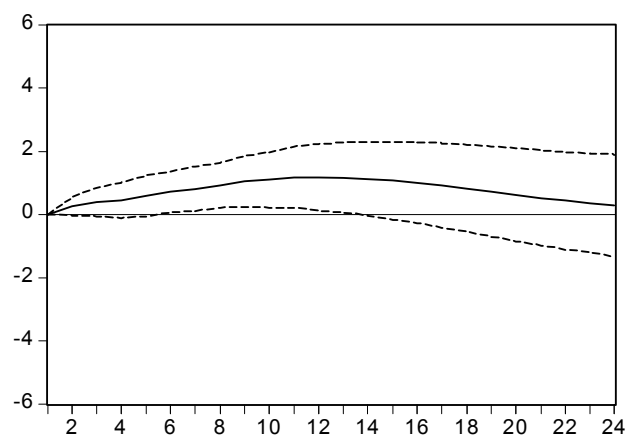

Response to FININNOV

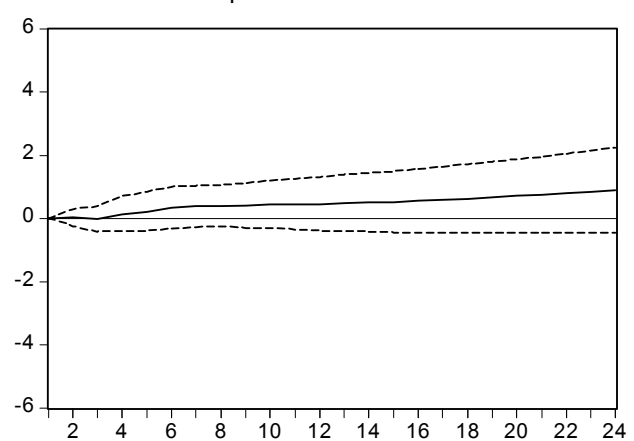




\section{APPENDIX}

\section{Definition of DAta VARIAbleS}

\begin{tabular}{ll}
\hline \multicolumn{1}{c}{ Variable Name } & \\
& \\
CPI & Consumer price index (1995=100) \\
FXRATE & Official U.S. dollar exchange rate (Z\$/US\$, period average) \\
CUR & Currency circulation \\
RESM & Reserve money \\
MONEY & Narrow money (comprises currency outside banks and banks' \\
& demand deposits) \\
M2 & Broad money (comprises narrow money and banks' time, savings, \\
& and foreign currency deposits) \\
RGDP & Real gross domestic product \\
TBRATE & Treasury bill interest rate (3 months) \\
TDRATE & Time deposit interest rate (3 months) \\
SPREAD & Difference between time deposits and treasury bill interest rates \\
FININNOV & Ratio of broad money to currency in circulation \\
INFLATION & Year-on-year change in the consumer price index \\
DEPRECIATION & Year-on-year change in the U.S. dollar exchange rate \\
RCUR & CUR deflated by the consumer price index \\
RRESM & RESM deflated by the consumer price index \\
RMONEY & MONEY deflated by the consumer price index \\
RM2 & M2 deflated by the consumer price index \\
&
\end{tabular}

Notes: All variables have been converted into logarithmic units, except interest rates, and seasonally adjusted, except the exchange rate and interest rates, for which data indicated no seasonality. Seasonally adjusted time series were calculated by the X-12 ARIMA procedure, developed by the U.S. Department of Commerce, Bureau of Census, and available through EViews, version 4. Some estimations were conducted using PcGive, version 10.

Sources: International Monetary Fund, International Financial Statistics; real GDP data are from Reserve Bank of Zimbabwe (1999). 


\section{REFERENCES}

Bernanke, Ben, and Alan Blinder, 1990, "The Federal Funds Rate and the Channels of Monetary Transmission,” NBER Working Paper No. 3487, Cambridge, Massachusetts: National Bureau of Economic Research.

Choudhri, Ehsan U., and Dalia S. Hakura, 2001, "Exchange Rate Pass-Through to Domestic Prices: Does the Inflationary Environment Matter?” IMF Working Paper 01/194 (Washington: International Monetary Fund).

Cottarelli, Carlo, and Curzio Giannini, 1997, Credibility Without Rules? Monetary Frameworks in the Post-Bretton Woods Era, IMF Occasional Paper No.154, Washington: International Monetary Fund.

Easterly, William, and Stanley Fischer, 2001, "Inflation and the Poor," Journal of Money, Credit and Banking, Vol. 33, Part 1 (May), pp.160-78.

Eichengreen, Barry, Paul Masson, Miguel Savastano, and Sunil Sharma, 1999, "Transition Strategies and Nominal Anchors on the Road to Greater Exchange-Rate Flexibility," Essays in International Finance, No. 213, Princeton University, Princeton, New Jersey.

Fischer, Stanley, 1993, "Role of Macroeconomic Factors in Growth," Journal of Monetary Economics, Vol. 32, pp. 485-512.

Gelbard, Enrique A., and Sérgio Pereira Leite, 1999, "Measuring Financial Development in Sub-Saharan AfricaIMF Working Paper 99/105 (Washington: International Monetary Fund).

International Monetary Fund, International Financial Statistics (Washington, several issues). , 2002, World Economic Outlook, May (Washington).

, World Economic Outlook, September (Washington).

Jenkins, Carolyn, 1999, "Money Demand and Stabilization in Zimbabwe," Journal of African Economies, Vol. 8 (October), pp. 386-421.

Johansen, Søren, and Katarina Juselius, 1990, "Maximum Likelihood Estimation and Inference on Cointegration, with Applications to the Demand for Money," Oxford Bulletin of Economics and Statistics, Vol. 52 (May), pp. 169-210.

Kmenta, Jan, 1986, Elements of Econometrics, second edition, Macmillan Publishing Company, New York. 
Kochhar, Kalpana, 1996, “The Definition of Reserve Money: Does it Matter for Financial Programs?" IMF Paper on Policy Analysis and Assessment 96/9 (Washington: International Monetary Fund).

MacKinnon, James G., 1991, "Critical Values for Cointegration Tests," in Engle and Granger, eds., Long-run Economic Relationships: Readings in Cointegration, Oxford University Press.

Nyawata, Obert, 2001, “The Demand for Money in Zimbabwe,” unpublished, Washington, International Monetary Fund.

Odedokun, M.O., 1997, "Dynamics of Inflation in Sub-Saharan Africa: The Role of Foreign Inflation, Official and Parallel Market Exchange Rates, and Monetary Growth," Applied Financial Economics, Vol. 7 (August) pp. 395-402.

Reserve Bank of Zimbabwe, 1999, Quarterly Economic and Statistical Review (December).

Sriram, Subramanian S., 2001, “A Survey of Recent Empirical Money Demand Studies," Staff Papers, International Monetary Fund, Vol. 47, No. 3, pp. 334-65. 